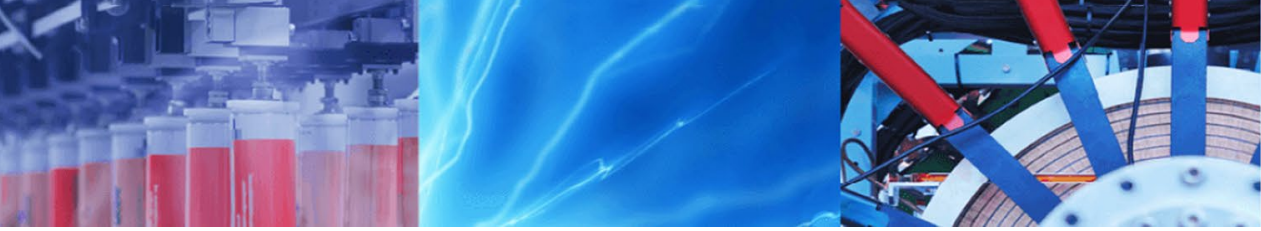

Research Article

\title{
Potential biocontrol and superlative plant growth promoting activity of indigenous Bacillus mojavensis PB-35(R11) of soybean (Glycine max) rhizosphere
}

\author{
Bobde M. Prajakta ${ }^{1,2} \cdot$ Patil P. Suvarna ${ }^{1} \cdot$ Singh P. Raghvendra ${ }^{3} \cdot$ Rai R. Alok $^{2}$
}

C Springer Nature Switzerland AG 2019

\begin{abstract}
Disease control using microbes that exhibit beneficial effects on plants to strengthen the host is a foremost requirement in agriculture. The aim of the present study is to search for an effective biocontrol agent against Rhizoctonia solani endowed with high plant growth potential. A total of 95 bacterial strains were isolated from the soybean plant rhizosphere and screened in vitro against $R$. solani by dual culture technique, revealing that strain PB-35(R11) was the most efficient for controlling $R$. solani with $54.835 \%$ inhibition. Isolate PB-35 was identified by $16 \mathrm{~S}$ ribosomal RNA (rRNA) gene sequencing as Bacillus mojavensis. It was observed that, in order to effectively control $R$. solani in vitro, B. mojavensis produced volatile metabolites. Fourier-transform infrared (FTIR) analysis revealed the presence of aldehyde (CHO) group $\left(1739.79 \mathrm{~cm}^{-1}\right)$, acetyl group $\left(1896.03 \mathrm{~cm}^{-1}\right)$, and cyanide group $\left(2360.87 \mathrm{~cm}^{-1}\right)$ in the crude extract of isolate PB-35(R11). Furthermore, the siderophore, indole acetic acid (IAA), catalase, oxidase, and chitinase production ability as well as phosphate solubilization potential of PB-35(R11) make it beneficial for crop growth and soil biofortification.
\end{abstract}

Keywords Soybean $\cdot$ Rhizosphere $\cdot$ Antagonistic activity $\cdot 16 \mathrm{~S}$ rRNA $\cdot$ Soil fortification

\section{Introduction}

Pathogenic microorganisms affect plant health and represent a major ongoing threat to sustainable agriculture and ecosystem stability worldwide. Chemicals used in agriculture to increase yields and kill pathogens, pests, and weeds have a harmful impact on the ecosystem. Because of current public concern about the side effects of agrochemicals, there is increasing interest in improving understanding of the cooperative activities among plants and rhizosphere microbial populations and an urgent need for biological agents. Use of plant growth promoting rhizobacteria (PGPR) is a better alternative to solve this problem [22].

Over $95 \%$ of bacteria exist in plant roots, and host plants obtain many nutrients through soil bacteria. Hence, this should be the richest source to explore to identify potential PGPR which may be useful for development of bioinoculants for growth and yield enhancement of crop plants [47]. Agricultural products are the primary dietary source of proteins, carbohydrates, fat, vitamins, and other nutrients. Soybean (Glycine max L. Merrill) is one of the best "all-in-one" sources, having very high nutritional value. To achieve good health, consumption of healthy food is the main concern, being directly related to the present agroecosystem. As populations increase, the need for dietary sources is increasing greatly day by day. This high demand has resulted in excessive use of different chemicals in the form of phytohormones and pesticides to promote plant growth and address pathogens, respectively, to obtain quick results [25]. However, due to the extreme diversity of pathogens and serious diseases, severe plant loss and yield

$\triangle$ Rai R. Alok, prof.alokrrai@gmail.com; alok.rrai@gmail.com | 'Department of Botany, Taywade College, Koradi, Tal. Kamptee, Nagpur, Maharashtra 441111, India. ${ }^{2}$ Department of Microbiology, S K Porwal College, Kamptee, Nagpur, Maharashtra 441001 , India. ${ }^{3}$ Department of Research and Development, Biotechnology, Uttaranchal University, Dehradun 248007, India.

SN Applied Sciences (2019) 1:1143 | https://doi.org/10.1007/s42452-019-1149-1

Received: 10 April 2019 / Accepted: 22 August 2019 / Published online: 4 September 2019 
reduction are common in susceptible soybean cultivars $[57,58]$. Rhizoctonia solani is one of the most important soil-borne fungal pathogens, developing in both cultured and noncultured soils in the form of sclerotia that do not generate asexual spores [6]. Damping-off of seedlings is the most common disease caused by $R$. solani [35]. Use of fungicides to control soil-borne disease is costly and also results in environmental and human health hazards, as well as adversely affecting beneficial microorganisms in the soil [12]. Biological control of soil-borne plant pathogens using treatment of seeds with antagonists has recently emerged as a promising alternative to the use of synthetic pesticides [15, 48]. Bacillus is a Gram-positive, facultative anaerobic, endospore-forming bacterial genus, being the most abundant in the soil rhizosphere, where naturally occurring soil bacteria aggressively colonize plant roots and benefit plants by promoting growth $[13,18,21,57]$. Jain et al. [25] isolated 10 bacterial strains from soybean rhizosphere and studied their effect on soybean plant growth promotion, revealing potential for phosphate solubilization, IAA production, and $\mathrm{N}_{2}$ fixation activity. In the work presented herein, rhizospheric isolates from soybean plant rhizosphere soil were identified and screened for their antagonism towards a fungal pathogen $R$. solani, which causes damping-off disease in soybean. Furthermore, the isolates were characterized regarding their abiotic stress tolerance, certain plant-beneficial activities (phosphate solubilization and IAA production), and plant growth promotion in greenhouse condition.

\section{Materials and methods}

\subsection{Field sites, soil sampling, and physicochemical characterization}

Different representative sampling sites with soybean cultivation from Kamptee region (Nagpur) in Maharashtra, India (five different villages: Ajni, Ranala, Kalamna, Gada, and Awandi) were surveyed and sampled for soybean rhizospheric soil (Table 1).

Soil samples were collected aseptically after careful uprooting plants and removing excess soil by shaking the plant thoroughly. The adherent soil was collected in sterile plastic bags. Each sample was divided into two partsone part was air dried and used to analyze soil properties, while the other was stored at $4{ }^{\circ} \mathrm{C}$ for further microbial community analysis. The physicochemical properties of the soils were analyzed as per standard methods [34]. All samples were tested and analyzed for $\mathrm{pH}$, electrical conductivity $(E C)$, and nitrogen $(N)$, phosphorus $(P)$, potassium $(\mathrm{K})$, and organic carbon (C) content (Table 1).

\subsection{Isolation and culture condition}

A total of 95 different rhizobacterial strains were isolated from the rhizospheric soil samples of soybean plants by serial dilution technique [20] and heat treatment method [56] on five different isolation agars, viz. actinomycete isolation agar, Pseudomonas isolation agar, oatmeal agar, nutrient agar, and ISP-2 medium, and incubated at $37^{\circ} \mathrm{C}$ for $24 \mathrm{~h}$. The total viable count was calculated by counting colony-forming units (CFUs) per gram of soil. Furthermore, colonies were purified and stored at $4{ }^{\circ} \mathrm{C}$ as well as $-20^{\circ} \mathrm{C}$ for routine study and long-term glycerol storage, respectively. The fungal pathogen $R$. solani used in the present study was obtained from the National Fungal Culture Collection of India (NFCCl-188) Agharkar Research Institute, Pune.

\subsection{Antagonism assay}

Isolates were screened by antagonism test against $R$. solani using dual culture assay technique as described by Rabha et al. [39]. Degree of antagonism was determined by measuring the mycelial growth of the pathogen and inhibition zone after $72 \mathrm{~h}$ of incubation. The percentage inhibition of mycelial growth was calculated on the 7th and 14th day of an experiment using the equation [41].

Table 1 Physiological parameters of soil from five sampling sites

\begin{tabular}{lllllllllll}
\hline Soil code & \multicolumn{1}{l}{ Parameters } \\
\cline { 2 - 10 } & Soil pH & $\mathrm{EC}$ & $\mathrm{N}\left(\mathrm{kg} \mathrm{ha}^{-1}\right)$ & $\mathrm{P}\left(\mathrm{kg} \mathrm{ha}^{-1}\right)$ & $\mathrm{K}\left(\mathrm{kg} \mathrm{ha}^{-1}\right)$ & $\mathrm{OC}(\%)$ & $\mathrm{Cu}(\mathrm{ppm})$ & $\mathrm{Fe}(\mathrm{ppm})$ & $\mathrm{Zn} \mathrm{(ppm)}$ & $\mathrm{Mn}(\mathrm{ppm})$ \\
\hline Soil no. I & 7.2 & 0.96 & 125.0 & 75.8 & 62.5 & 0.37 & 0.44 & 0.33 & 0.39 & 3.11 \\
Soil no. II & 7.4 & 0.91 & 129.0 & 63.7 & 55.2 & 0.32 & 0.39 & 0.31 & 0.41 & 2.21 \\
Soil no. III & 7.7 & 0.98 & 105.0 & 80.2 & 49.8 & 0.28 & 0.41 & 0.38 & 0.27 & 2.84 \\
Soil no. IV & 7.8 & 1.01 & 19.0 & 71.6 & 68.3 & 0.35 & 0.47 & 0.29 & 0.42 & 2.65 \\
Soil no. V & 7.5 & 0.95 & 142.0 & 62.8 & 65.7 & 0.35 & 0.45 & 0.31 & 0.37 & 3.27 \\
\hline
\end{tabular}

Physicochemical properties of soil: EC, electrical conductivity; N, nitrogen; P, phosphorus, K, potaash; OC, organic carbon; Cu, copper, Fe, iron; $\mathrm{Zn}$, zinc; $\mathrm{Mn}$, manganese 
Percentage of inhibition $=\frac{C-T}{C} \times 100$,

where $C$ is the radial growth of fungus in control plates $(\mathrm{mm})$ and $T$ is the radial growth of fungus on a plate inoculated with each antagonist $(\mathrm{mm})$.

\subsection{Microscopy of fungal mycelia}

Morphological changes caused by the antagonistic bacterium Bacillus mojavensis PB-35(R11) on the mycelia of the phytopathogenic $R$. solani after culturing on potato dextrose agar (PDA) plates for 6-7 days were examined directly under phase-contrast microscopy (Metzer Ltd.) and scanning electron microscopy (SEM) as described by Torres et al. [54].

\subsection{Phenotypes of bacterial isolates}

Colony morphology, size, shape, elevation, margin, color, and aerobic/anaerobic nature were recorded after $24-48 \mathrm{~h}$ of growth on nutrient agar plates at $28 \pm 2{ }^{\circ} \mathrm{C}$ as described by Somasegaran and Hoben [49]. Gram reaction was performed as described by Vincent and Humphrey [55]. The motility of native isolates was studied by the hanging drop technique described by Cappuccino and Sherman [7, 8]. A series of biochemical tests were conducted using standard methods. The growth at varying temperatures $\left(45^{\circ} \mathrm{C} 50^{\circ} \mathrm{C}\right.$, $55^{\circ} \mathrm{C}$, and $60^{\circ} \mathrm{C}$ ) was also studied.

\subsection{Biochemical characteristics of isolates}

Catalase assay was performed according to Hayward [23]. Briefly, a few drops of $30 \% \mathrm{H}_{2} \mathrm{O}_{2}$ were added to logphase rhizobacterial culture pellets on a glass slide. The appearance and intensity of gas bubbles were observed for catalase activity. For oxidase assay, tested isolates were spotted onto trypticase soya agar plates and incubated for $24 \mathrm{~h}$ at $28 \pm 2^{\circ} \mathrm{C}$. After incubation, two to three drops of tetramethylethylenediamine (TEMED) were added to the surface of the test organism, and a color change to maroon was taken as positive for oxides [40]. Production of urease was demonstrated by stab-inoculating the culture into Christensen's urea agar medium. The tubes were incubated at $30^{\circ} \mathrm{C}$ for $24 \mathrm{~h}$, and degradation of urea was indicated by a change in color of the medium in the test tubes, with purple-pink indicating a positive result [8]. Chitinase production was evaluated as described previously [33]. Briefly, a log-phase culture of the tested strain was inoculated by a single streak on chitin medium plates then incubated at $30^{\circ} \mathrm{C}$ for $24 \mathrm{~h}$. Then $0.1 \%$ Congo Red solution was spread over the plates, with clear halos around and beneath the growth indicating enzymatic degradation, measured after 5-14 days of incubation. Different sugars were used as nutrient sources to analyze the hydrolysis potential of tested strains [27]. Briefly, different sugars (dextrose, lactose, mannitol, maltose, fructose, and sucrose) were taken in test tubes, each containing sufficient amount of beef extract and peptone. To detect acid formation, phenol red was added as $\mathrm{pH}$ indicator, and test tubes inoculated with bacterial culture and six control test tubes were incubated at $30 \pm 2{ }^{\circ} \mathrm{C}$ for $24 \mathrm{~h}$. The temperature tolerance ability of the studied isolates was evaluated in nutrient broth medium inoculated with $5 \mu$ l log-phase culture. The inoculated flasks were incubated at $45^{\circ} \mathrm{C}$, $50{ }^{\circ} \mathrm{C}, 55^{\circ} \mathrm{C}$, and $60^{\circ} \mathrm{C}$, and the growth was observed by spectrophotometer after 24-72 $\mathrm{h}$.

\subsection{Plant growth promoting (PGP) characteristics}

Phosphate solubilization ability was revealed by dissolution of precipitated tricalcium phosphate $\left[\mathrm{Ca}_{3}\left(\mathrm{PO}_{4}\right)_{2}\right]$ in agar medium [37], estimated quantitatively according to the procedure described by Farhat et al. [17]. For potassium and zinc solubilization assays, inoculum of isolates was spotted onto Aleksandrov medium and zinc oxide ( $\mathrm{ZnO})$ in agar medium, respectively [20]. Screening of bacterial isolates for hydrogen cyanide $(\mathrm{HCN})$ production was carried out using cultures grown on King's B medium with alkaline picric acid as indicator [4]. $\mathrm{N}_{2}$ fixation was tested by inoculating bacterial isolates in glucose nitrogen free mineral medium (G-NFMM) containing bromophenol blue solution (BTB) for 1 week at $28^{\circ} \mathrm{C}$ [29]. Qualitative production of IAA was tested according to the procedure described by Singh et al. [47]. A loopful of bacterium was inoculated and incubated into presterilized peptone broth for $48 \mathrm{~h}$ at $37^{\circ} \mathrm{C}$. After $48 \mathrm{~h}, 1 \mathrm{ml}$ Kovac's reagent was added to all tubes, including control, and shaken after $15 \mathrm{~min}$. The appearance of a red ring at the top is a clear indication of IAA production. IAA production was tested quantitatively according to the procedure described by Ahmad [2]. Qualitative and quantitative assay of chitinase production was carried out according to previously described procedures [33]. Siderophore production was tested qualitatively using chromeazurol $S$ (CAS) medium [43].

\subsection{Fermentation and extraction of crude metabolites}

Based on the zone of inhibition in primary screening, B. mojavensis PB-35(R11) was investigated to extract metabolites produced during antagonism. Briefly, logphase culture of $B$. mojavensis $\mathrm{PB}-35(\mathrm{R} 11)$ was grown in nutrient broth $(1000 \mathrm{ml})$ at $37^{\circ} \mathrm{C}$ for 6 days. The cell mass was then separated by centrifugation at $5000 \mathrm{rpm}$ 
followed by addition of $50 \%$ ethyl acetate $(500 \mathrm{ml})$ to fermented broth cultures and vigorous shaking for $20 \mathrm{~min}$, then left to stand to obtain a clear solvent phase and aqueous phase. To concentrate the antimicrobial metabolites produced by the isolate, the clear solvent phase was separated, evaporated in a vacuum drier, and subjected to FTIR analysis.

\subsection{FTIR analysis}

FTIR analysis was performed to investigate the presence of different functional groups in the antifungal compounds (extracted secondary metabolites) of $B$. mojavensis PB-35(R11). The FTIR analysis was carried out using a Thermo Scientific Nicolet iS50FTIR in the mid-IR region of $400-4000 \mathrm{~cm}^{-1}$ with 16 scan speeds. The sample was prepared using pure $\mathrm{KBr}(5: 95)$. Electromagnetic radiation ranging between $2500 \mathrm{~nm}$ and $20,000 \mathrm{~nm}$ was passed through a sample and absorbed in bands by stretching or bending of molecules in the sample. The absorbed wavelengths are characteristic of the absorbing bond. The pellets were fixed in the sample holder and analyzed.

\subsection{Molecular characterization}

Genomic DNA (gDNA) extraction was carried out as described by Pospiech and Neumann [37]. The amplified $16 \mathrm{~S}$ rRNA gene was obtained from isolated gDNA by polymerase chain reaction (PCR) using universal primers $\mathrm{PA}$ and $\mathrm{PH}$ as described previously [46]. The presence and yield of specific PCR products was checked by $1 \%$ agarose (wt/vol) gel electrophoresis, visualized by ethidium bromide staining and ultraviolet (UV) transillumination. Further, the amplified 16S rRNA gene product was sequenced by Bangalore Geni (India). Sequences were identified and annotated by BLAST $_{\mathrm{N}}$ search analysis against National Center for Biotechnology Information (NCBI) database and deposited in GenBank. Alignment of gene sequences with retrieved datasets was performed by using the ClustalW program in MEGA version 5.0 software [51]. Phylogenetic analysis and the robustness of the tree topology were calculated by bootstrap analysis with 1000 replications of sequences for neighbor joining.

\subsection{Pot assay}

Pot assay was performed in a greenhouse chamber to evaluate the biocontrol potential as well as PGP characteristics of PB-35(R11), as described previously by Singh et al. [48]. Briefly, pre-surface-sterilized soybean seeds (variety 9305) were bacterized with $B$. mojavensis (PB-35) then transferred to pots prefilled with sterilized sand. Noninoculated seed as well as $R$. solani-treated sand pot seedlings were used as control. Further, seed germination, plant length, root length, shoot length, plant fresh weight, plant dry weight, and nodule numbers were recorded. Chlorophyll content in experimental plant leaves was calculated as described by Ferjani et al. [17]. All experiments were carried out in six replicates in greenhouse condition.

\subsection{Statistical analysis}

Data were subjected to one-way analysis of variance (ANOVA), and means were compared by Duncan's multiple-range test [13].

\section{Results}

\subsection{Soil analysis}

The physicochemical properties of the soils were analyzed using standard methods, revealing $\mathrm{pH}$ of 7.2-7.8, electrical conductivity of $0.91-1.01$, nitrogen content of $19-142 \mathrm{~kg} \mathrm{ha}^{-1}$, phosphorus content of $62.8-80.2 \mathrm{~kg} \mathrm{ha}^{-1}$, potaash content of 49.8-68.3 kg ha ${ }^{-1}$, organic carbon content of $0.28-0.37 \%$, and copper content of $0.39-0.47 \mathrm{ppm}$ (Table 1). Microbiological studies were conducted and revealed the presence of bacteria in soil samples obtained from the rhizosphere of soybean at different sites of Kamptee region (Nagpur) in Maharashtra, India.

\subsection{Isolation, identification, and characterization of screened antagonistic bacteria}

The total viable counts of bacteria in different ecological niches from the five soil samples varied from 6.27875 to $8.17609 \log$ CFU/g soil. A total of 95 rhizobacterial strains were isolated from the soybean rhizospheric soil samples. All strains were screened for in vitro antagonistic activity. Among 95 isolates, 45 showed inhibitory activity against $R$. solani. The antagonistic effectiveness of the bacterial isolates varied from moderate to excellent, as revealed by their aggressive antifungal activity with inhibition zones $>20 \mathrm{~mm}$. Among them, strain PB-35(R11) exhibited potent antagonistic activity against $R$. solani, with the largest inhibition zone of $40 \mathrm{~mm}$ and inhibition of $54.285 \%$, suggesting a novel source for isolation and application of this potent isolate for biological control of damping-off disease in soybean.

Strain identification is one of the most powerful approaches to determine the genus and species of isolates that do not fit any recognized biochemical profiles, for strains generating only a "low likelihood" or "acceptable" identification using commercial systems [26, 52]. 
Hence, the screened PB-35(R11) strain was identified as B. mojavensis by $16 \mathrm{~S}$ rRNA gene annotation and BLAST search of NCBI.

The BLAST annotation result of the 16S rRNA gene revealed that PB-35(R11) is closest to B. mojavensis. Phylogenetic clustering was carried out using the neighbourjoining method for isolate PB-35(R11) along with the closest lineages of the genus Bacillus (Fig. 1). The phylogenetic tree constructed for the partial 16S rRNA gene sequence ( $>1400 \mathrm{pb})$ of $\mathrm{PB}-35$ (R11) clustered with the clade of Bacillus sp. (JQ236812), B. sonorensis (LN997930), B. subtilis (HQ678662), and B. mojavensis (JF901760). The characterized sequence was deposited in the NCBI database under accession no. MH646673 (B. mojavensis R11 strain PB-35), and culture was deposited to the National Culture Collection Center NAIMCC Mau under accession no. NAIMCC-B-02050.

\subsection{Microscopy of fungal mycelia}

The inhibition of fungal growth by $B$. mojavensis PB$35(\mathrm{R} 11)$ in a dual culture was visualized by phase-contrast microscopy (Fig. 2a-c). The interaction between the promising strain PB-35(R11) and the fungal pathogen R. solani was also investigated by SEM (Fig. 2). The micrographs clearly revealed inhibition of apical growth of hyphae, curling of fungal mycelia tips, and irregular distortions in fungal hyphae in the presence of bacterial antagonist (Fig. 2e-f). Micrographs of control treatment showed intact mycelia (Fig. 2d).

\subsection{FTIR spectroscopy}

The FTIR spectrum of the crude extract from the bacterial isolate showed strong absorption bands at 1739.79 , 1896.03 , and $2360.87 \mathrm{~cm}^{-1}$ (Fig. 3), which can be attributed to aldehyde (CHO), acetyl, and cyanide groups, respectively.

\subsection{Morphological and biochemical characterization of bacterial isolate}

The characteristics of PB-35(R11) colonies are described in Table 2. PB-35(R11) was cream-colored and opaque, being slightly irregular in shape, rough, and bulging upward. PB-35 was aerobic with round-ended rods and motile, testing positive for Gram stain, endospore, catalase, chitinase, dextrose, maltose, sucrose, mannitol, fructose, Voges-Proskauer (V-P), and citrate utilization but negative for oxidase, urease, lactose, methyl red (MR), and indole.
Fig. 1 Phylogenetic tree based on nucleotide sequences of 16S rRNA gene of $B$. mojavensis PB-35(R11)

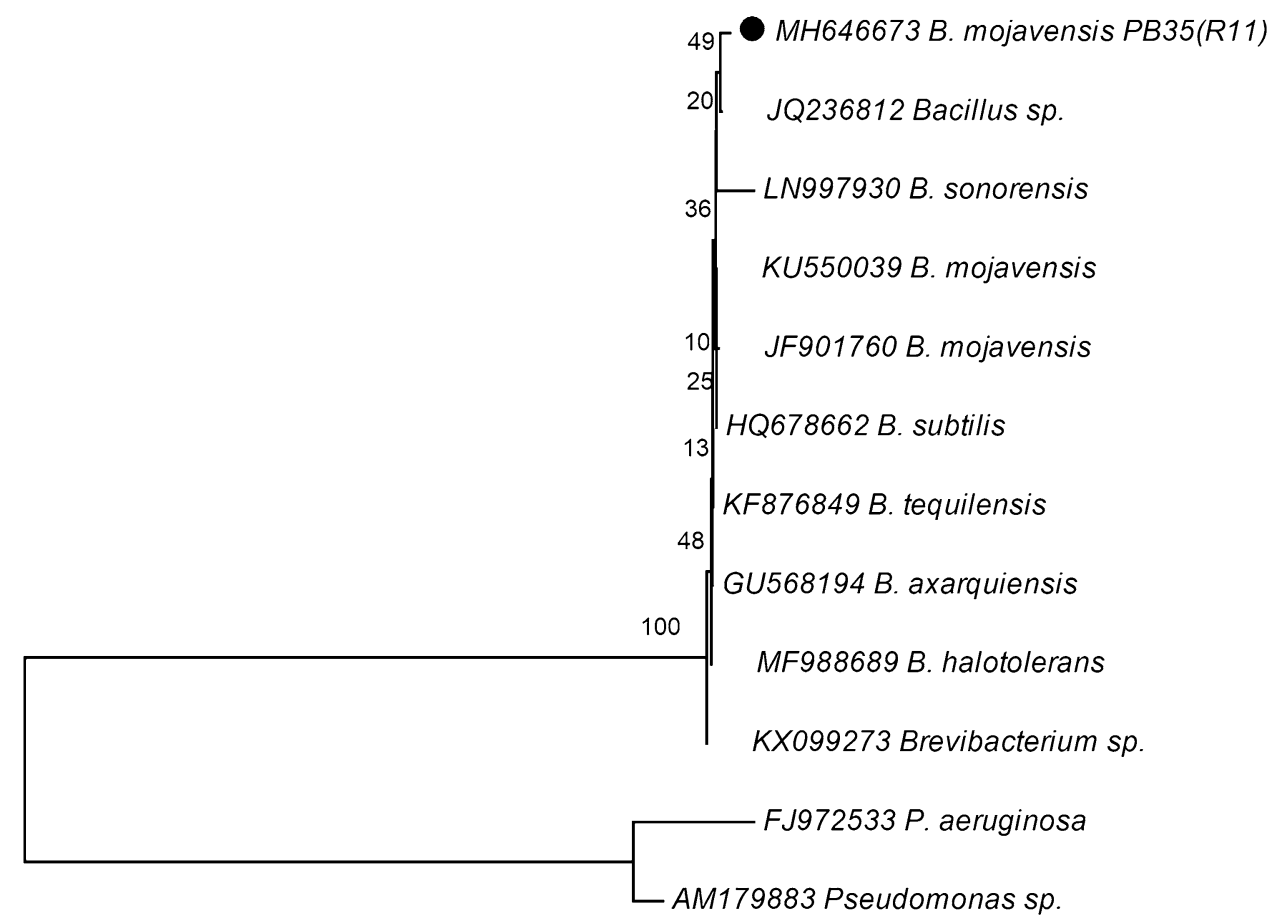

0.05 


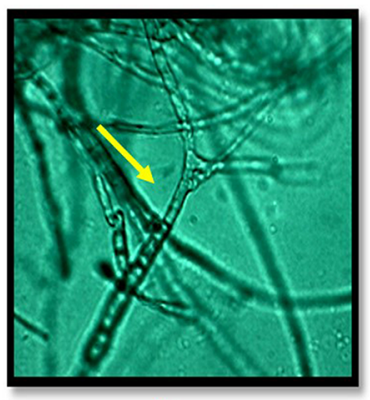

a

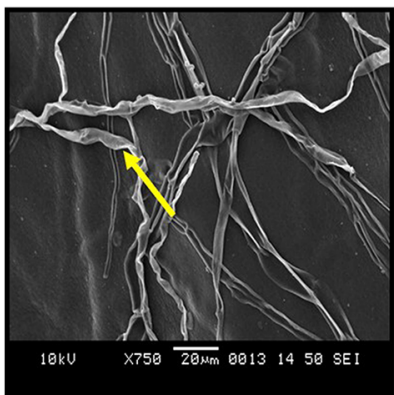

d

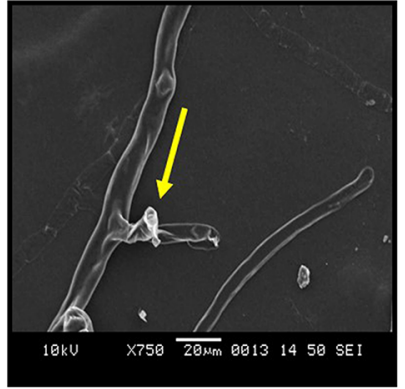

e

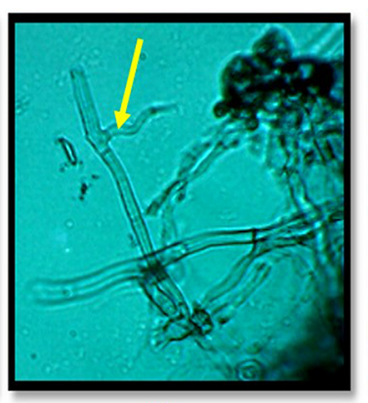

b

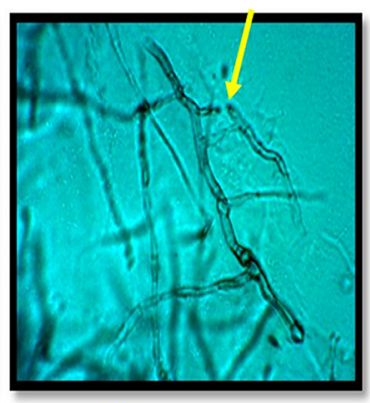

C

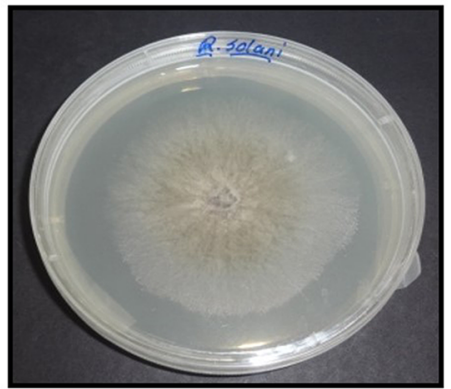

f

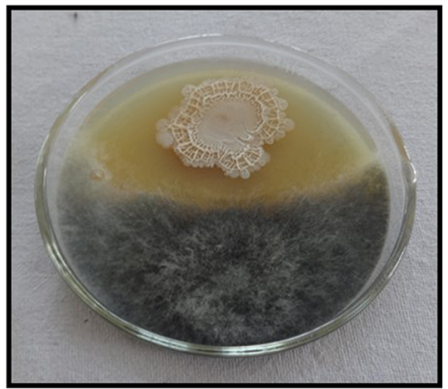

g
Fig. 2 Phase-contrast microscopy of inhibition of fungal growth by $B$. mojavensis PB-35(R11) in dual culture. a Control culture with only $R$. solani. b, $\mathbf{c} R$. solani mycelia from the edge of the inhibitory halo; yellow arrows indicate hyphal deformation. d, e SEM images

\subsection{Plant growth promoting (PGP) characteristics}

The PGP characteristics of strain PB-35(R11) were characterized and compared with those of other strains, being found positive for phosphate solubilization, nitrogen fixation activity, ammonia production, IAA production, hydrogen cyanide (HCN) production, chitinase production, and siderophore production but negative for zinc solubilization and potassium solubilization (Table 2 ). Qualitative analysis of culture supernatant revealed that the selected Bacillus strain PB-35(R11) was able to produce significant IAA with tryptophan but failed to produce it in the absence of L-tryptophan. Quantitative assay showed that PB-35(R11) produced $29 \pm 0.63 \mathrm{\mu g} \mathrm{ml}^{-1}$ IAA. Moreover, qualitative and quantitative assays of phosphate solubilization revealed a similar pattern to the IAA trait, quantified as $86.88 \pm 1.75 \mathrm{mg} \mathrm{ml}^{-1}$. Quantification assay of chitinase showed that PB-35(R11) produced $74.49 \pm 0.70$ units $\mathrm{mg}^{-1}$ protein of chitinase. $\mathrm{HCN}$, ammonia, and siderophore production were also found high in PB-35(R11).

\subsection{Greenhouse experiment}

The results of the pot trial revealed that PB-35(R11) was the best strain for inoculation of soybean plants in terms of PGP, resulting in significant elevation of nodule number, of B. mojavensis-R. solani interaction during dual culture of $R$. solani; yellow arrows indicate hyphal deformation and damaged mycelia of $R$. solani. $\mathbf{f}$ Control culture of $R$. solani. $\mathbf{g}$ Inhibition effect of antagonistic strain B. mojavensis on $R$. solani

root length, shoot length, fresh weight, dry weight, and total chlorophyll (Table 3; Fig. 4a). Inoculation of soybean seeds with $R$. solani effectively regressed all growth parameters, while inoculation with PB-35(R11) enhanced plant growth $(61.770 \pm 0.178)$ and offered protection from R. solani (Fig. 4). After treatment, the nodule number was significantly increased to $8.370 \pm 0.077$. Quantification of total chlorophyll revealed the highest content $(1.265 \pm 0.124 \mathrm{mg} / \mathrm{g}$ leaf fr.wt) as compared with control as well as $R$. solani-treated seed (Table 3 ).

\section{Discussion}

The most important biocontrol agents for plant diseases are antagonistic bacteria [48, 51]. Previously, Ester et al. [14] isolated 11 bacterial isolates from soybean, selected on the basis of their antagonistic activity and plant growth promoting traits. Dalal and Kulkarni [11] isolated a total of 31 endophytic bacteria from different parts, viz. roots, stem, leaf, and root nodules, of soybean (cv. JS-353) at different growth stages and screened them for their antagonistic activity against isolated soil-borne fungal pathogens and their plant growth promoting (PGP) activity. In the present study, among 95 soybean rhizosphere isolates, PB-35(R11) showed the greatest potential, with a a broad spectrum

\section{SN Applied Sciences}




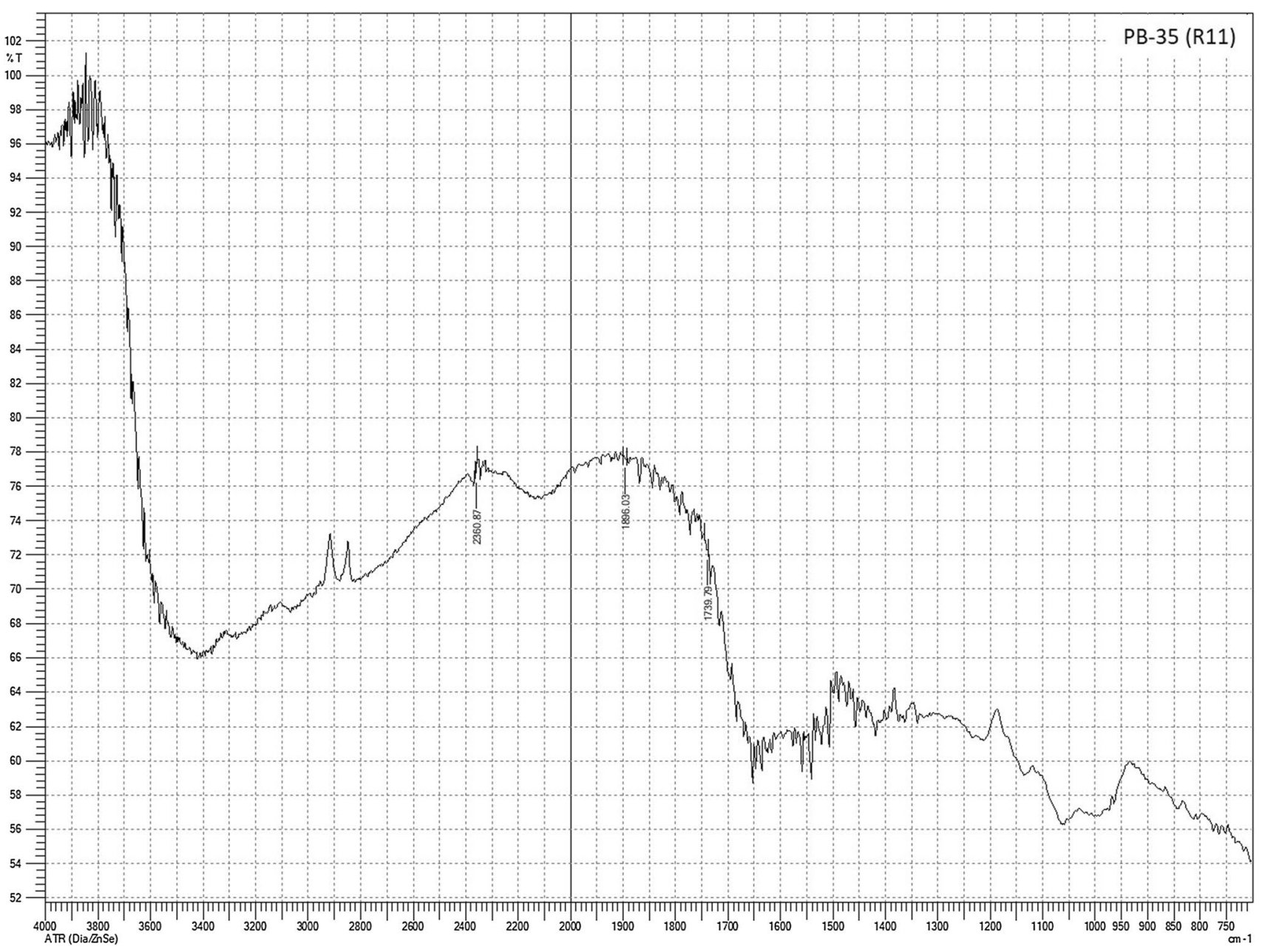

Fig. 3 FTIR spectrum of crude extract produced by B. mojavensis PB-35(R11)

of in vitro antagonistic activity towards the fungal pathogen as well as PGP traits. Many Bacillus isolates have been shown to exhibit activity against phytopathogenic fungi, making them good biocontrol candidates [32, 38, 44]. In the present study, strain B. mojavensis PB-35(R11) exhibited strong antifungal activity ( $40 \mathrm{~mm}$ zone of inhibition) against the fungal pathogen $R$. solani, which can mainly be attributed to its production of phosphate, ammonia, hydrogen cyanide, nitrogen-fixing activity, chitinase, IAA, and siderophore. For the selection of biocontrol agents, use of an appropriate screening system is important. One of the most convincing characteristics of Bacillus species contributing to the biocontrol mechanism is the synthesis of structurally diverse antibiotics with a broad spectrum of antifungal activity and the ability to modify attachment of other microorganisms to different surfaces [42, 50]. The antagonistic activity of Bacillus is associated with the synthesis of various antimicrobial peptides [16, 30], secreted enzymes [5], proteins [53], and volatile organic compounds (VOCs) $[5,10]$. Although the exact mode of action is not clear at present, the results of FTIR analysis indicated production of antibiotic and hydrolytic enzymes. FTIR analysis of crude compound identified functional groups such as aldehyde, acetyl, and cyanide. Meanwhile, strong antifungal activity was reported for aldehydegroup-containing cinnamaldehyde a-methylcinnamic acid by Cheng et al. [9] and volatile metabolites such as hydrogen cyanide by Ahmadzadeh et al. [3].

Several studies have reported that Bacillus strains can be used as biocontrol agents and plant growth promoting inoculants $[1,19,28,36,46]$. The antagonistic capabilities of $B$. licheniformis, B. subtilis, B. pumilis, and B. cereus have been demonstrated by several workers $[19,31,42,45]$. The highest IAA production was recorded for PB-35 $(p<0.05$; $29 \pm 0.63 \mathrm{mg} \mathrm{ml}^{-1}$ ) on the 6th day. Isolate PB-35(R11) produced the highest amount of chitinase in minimal broth supplemented with chitin, and the maximum chitinase production $\left(74.49 \pm 0.70\right.$ units $\mathrm{mg}^{-1}$ protein) was recorded after 9 days of inoculation in minimal media (Table 2). Greenhouse data of plant growth showed high chlorophyll 
Table 2 Morphological, biochemical, physiological, and PGPR characteristics of B. mojavensis PB 35(R11)

\begin{tabular}{|c|c|c|}
\hline S. no. & Test & Result \\
\hline \multicolumn{3}{|c|}{ Morphological characteristics } \\
\hline 1. & Gram reaction & + \\
\hline 2. & Motility & + \\
\hline 3. & Colony color & Cream \\
\hline 4. & Colony shape & $\begin{array}{l}\text { Circular, } \\
\text { smooth, } \\
\text { opaque }\end{array}$ \\
\hline 5. & Endospore & + \\
\hline 6. & Cell shape & Rod \\
\hline 7. & Aerobic/anaerobic & Aerobic \\
\hline \multicolumn{3}{|c|}{ Biochemical traits } \\
\hline 8. & Catalase & + \\
\hline 9. & Oxidase & + \\
\hline 10. & Urease & - \\
\hline 11. & Chitinase & + \\
\hline 12. & Dextrose & + \\
\hline 13. & Maltose & + \\
\hline 14. & Sucrose & + \\
\hline 15. & Mannitol & + \\
\hline 16. & Fructose & + \\
\hline 17. & Lactose & - \\
\hline 18. & Methyl red test & - \\
\hline 19. & Voges-Proskauer test & + \\
\hline 20. & Indole & - \\
\hline 21. & Citrate & + \\
\hline \multicolumn{3}{|c|}{ Physiological trait } \\
\hline 22. & Temperature range $\left({ }^{\circ} \mathrm{C}\right)$ & $10-50$ \\
\hline \multicolumn{3}{|c|}{ PGPR traits } \\
\hline 23. & Phosphate solubilization $\left(\mathrm{mg} \mathrm{ml}^{-1}\right)$ & $86.88 \pm 1.75$ \\
\hline 24. & Zinc solubilization & - \\
\hline 25. & Potassium solubilization & - \\
\hline 26. & Nitrogen fixation & + \\
\hline 27. & Ammonia production & + \\
\hline 28. & IAA production $\left(\mu \mathrm{g} \mathrm{ml}^{-1}\right)$ & $29 \pm 0.63$ \\
\hline 29. & Chitinase activity (units $\mathrm{mg}^{-1}$ protein) & $74.49 \pm 0.70$ \\
\hline 30. & HCN production & + \\
\hline 31. & Siderophore production & + \\
\hline
\end{tabular}

$(+)=$ positive result $;(-)=$ negative result; values expressed as mean \pm standard deviation (SD)

Table 3 Biocontrol and plant growth promoting effect of B. mojavensis PB 35(R11) on soybean plant in greenhouse condition

\begin{tabular}{lllllll}
\hline Treatment & NN & RL $(\mathrm{cm})$ & SL $(\mathrm{cm})$ & FW (g/plant) & DW (g/plant) & TC (mg/g fresh weight) \\
\hline Control & $5.891^{\mathrm{b}} \pm 0.0636$ & $7.226^{\mathrm{b}} \pm 0.0638$ & $21.803^{\mathrm{b}} \pm 0.120$ & $53.55^{\mathrm{b}} \pm 0.221$ & $13.193^{\mathrm{b}} \pm 0.077$ & $0.700^{\mathrm{b}} \pm 0.011$ \\
Control+RS & $3.820^{\mathrm{a}} \pm 0.0755$ & $5.136^{\mathrm{a}} \pm 0.008$ & $20.440^{\mathrm{a}} \pm 0.166$ & $47.31^{\mathrm{a}} \pm 0.183$ & $10.430^{\mathrm{a}} \pm 0.187$ & $0.423^{\mathrm{a}} \pm 0.013$ \\
Control+RS+PB35 & $8.370^{\mathrm{c}} \pm 0.077$ & $8.610^{\mathrm{c}} \pm 0.0862$ & $24.803^{\mathrm{c}} \pm 0.074$ & $61.770^{\mathrm{c}} \pm 0.178$ & $21.940^{\mathrm{c}} \pm 0.090$ & $1.265^{\mathrm{c}} \pm 0.124$ \\
$\quad(\mathrm{R} 11)$ & & & & & & \\
\hline
\end{tabular}

$\mathrm{NN}$, nodule number; RL, root length; SL, shoot length; FW, fresh weight; DW, dry weight; TC, total chlorophyll

Each value is the mean of six replicates \pm standard error (SE). Means followed by the same letter within a row are not significantly different at $p<0.05$, as determined by Duncan's multiple-range test

\section{SN Applied Sciences}




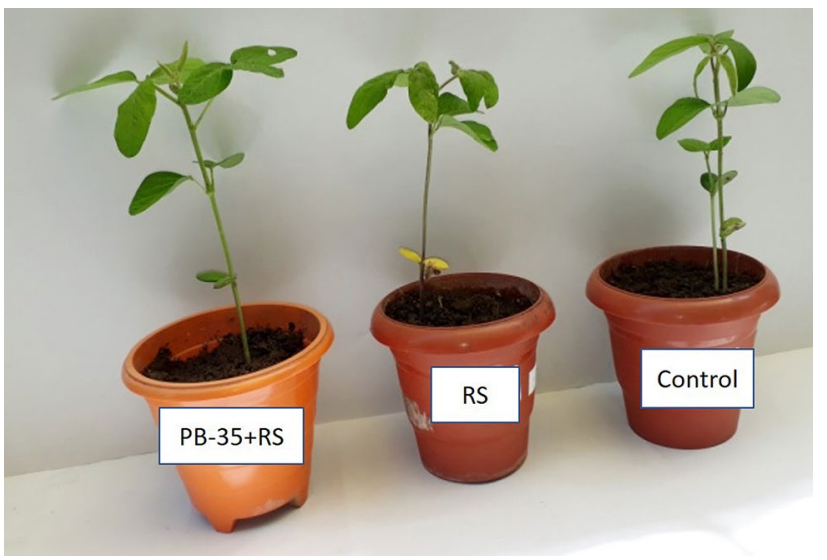

Fig. 4 Plant growth promotion effect on soybean plants of application of B. mojavensis PB-35(R11) treatment at $10^{9}$ spores $/ \mathrm{ml}$ and control as sterile soil with distilled water. Representation of soybean plant health and root system as affected by bacterial inoculation of seed plants calculated 60 days after sowing

content when using seeds treated with 70 units $\mathrm{mg}^{-1}$ B. mojavensis, which is positively related to plant growth because the rate of photosynthesis and the healthy of the plant canopy is based on chlorophyll [24]. The results for the the nodule number, root length, shoot length, fresh weight, and dry weight in the pot assay showed the effectiveness of PB-35(R11) for reduction of the severity of the disease caused by $R$. solani (Table 3 ).

\section{Conclusions}

A total of 95 bacterial strains were isolated from the rhizosphere of soybean plants and screened in vitro for their antagonistic potential against the most common soil pathogenic fungus $R$. solani. Among them, PB-35(R11) was found to be the best antagonist. Furthermore, the interaction between PB-35(R11) and $R$. solani was visualized by phase-contrast microscopy and SEM. The results of $16 \mathrm{~S}$ rRNA gene analysis and in silico nucleotide similarity search identified it as B. mojavensis. Furthermore, experiments were performed using $B$. mojavensis PB-35(R11) isolates to determine their PGP potential in terms of phosphate solubilization, siderophore production, nitrogenfixation activity, ammonia production, IAA production, $\mathrm{HCN}$ production, and chitinase production. FTIR analysis of crude extracts of PB35(R11) revealed the presence of various active metabolites and enzymes. Overall, the results of this study identify B. mojavensis PB-35(R11) as the best and most potent antagonistic strain, giving the optimum results. Thus, the PB-35(R11) strain possesses several key plant growth promoting characteristics and could be used as an important element in management of damping-off disease in soybean, as it is environmentally safe with no human health hazards, and economically favorable for farmers in comparison with synthetic chemicals. However, the success of biological approaches to control plant diseases and enhance plant growth depends upon their performance in field conditions. This prominent antagonistic bacterium is the leading candidate for further investigation into biological control of the $R$. solani pathogen.

Acknowledgements I am grateful to the University Grants Commission (UGC), New Delhi for providing financial support under Major Research Project F. No. 41-1177/2012 (SR).

\section{Compliance with ethical standards}

Conflict of interest The author's declare that they have no conflict of interest.

\section{References}

1. Ahemad M, Kibret M (2014) Mechanisms and applications of plant growth promoting rhizobacteria: current perspective. J King Saud Univ Sci 26:1-20

2. Ahmad F, Iqbal A, Mohd SK (2005) Indole acetic acid production by the indigenous isolates of Azotobacteria and fluorescent Pseudomonas in the presence and absence of tryptophan. Turk J Biol 29:29-34

3. Ahmadzadeh M, Hamideh A, Mohammad J, Abbas S (2006) Identification of some molecular traits in fluorescent pseudomonads with antifungal activity. Iran J Biotechnol 4:245-253

4. Bakker AW, Schippers B (1987) Microbial cyanide production in the rhizosphere in relation to potato yield reduction and Pseudomonas SPP-mediated plant growth-stimulation. Soil Biol Biochem 19:451-457

5. Baysal O, Lai D, Xu H, Siragusa M, Casiskan M, Carimi F, Silva JAT, Tor M (2013) A proteomic approach provides new insights into the control of soil-borne plant pathogens by Bacillus species. PLoS ONE 8:e53182

6. Cao L, Qui Z, You J, Tan H, Zhou S (2004) Isolation and characterization of endophytic Streptomyces strains from surface-sterilized tomato (Lycopersicon esculentum) roots. Lett Appl Microbiol 39:425-430

7. Cappuccino JG, Sherman N (1992) Microbiology: a laboratory manual, vol 125. Benjamin/Cummings, New York, p 179

8. Cappuccino JG, Sherman N (2002) Microbiology: a laboratory manual. Benjamin/Cummings, Harlow, pp 263-264

9. Cheng SS, Liu J, Chang E, Chang ST (2008) Antifungal activity of cinnamaldehyde and eugenol congeners against wood-rot fungi. Biores Technol 99:5145-5149

10. Choudhary DK, Johri BN (2009) Interactions of Bacillus spp. and plants with special reference to induced systemic resistance (ISR). Microbiol Res 164:493-513

11. Dalal J, Kulkarni N (2013) Antagonistic and plant growth promoting potentials of indigenous endophytic bacteria of soybean (Glycine max (L.) Merril). Curr Res Microbiol Biotechnol 1:62-69

12. Dluzneiwska J (2003) Reaction of fungi of Trichoderma genus to selected abiotic factors. Electron J Pol Agric Univ Agron 6:239-242

13. Duncan DB (1955) Multiple range and multiple F-tests. Biometrics 11:1-42 
14. Elshaghabee F, Rokana N, Gulhane RD, Sharma C, Panwar H (2017) Bacillus as potential probiotics: status, concerns, and future perspectives. Front Microbiol 8:1490

15. Ester S, Natalia PV, Marcela M, Carla Z, Karina B, Marcelo C (2015) Evaluation of native bacteria and manganese phosphite for alternative control of charcoal root rot of soybean. Microbiol Res 180:40-48

16. Falardeau J, Wise C, Novitsky L, Avis TJ (2013) Ecological and mechanistic insights into the direct and indirect antimicrobial properties of Bacillus subtilis lipopeptides on plant pathogens. J Chem Ecol 39:869-878

17. Farhat M, Boukhris I, Chouayekh H (2015) Mineral phosphate solubilization by Streptomyces sp. CTM396 involves the excretion of gluconic acid and is stimulated by humic acids. FEMS Microbiol Lett 362:008

18. Ferjani A, Laszlo M, Ronan S, Kay M, Iwane S, Martin H, Norio M (2003) Glucosylglycerol, a compatible solute, sustains cell division under salt stress. Plant Physiol 131:1628-1637

19. Gajbhiye A, Rai AR, Meshram SU, Dongre A (2010) Isolation, evaluation and characterization of Bacillus subtilis from cotton rhizospheric soil with biocontrol activity against Fusarium oxysporum. World J Microbiol Biotechnol 26:1187-1194

20. Ghevariya KK, Desai PB (2014) Rhizobacteria of sugarcane: in vitro screening for their plant growth promoting potentials. Res J Recent Sci 3:52-58

21. Graumann K, Irons SL, Runions J, Evans DE (2007) Retention and mobility of the mammalian lamin B receptor in the plant nuclear envelope. Biol Cell 99:553-562

22. Gupta G, Parihar SS, Ahirwar NK, Snehi SK, Singh V (2015) Plant growth promoting rhizobacteria (PGPR): current and future prospects for development of sustainable agriculture. J Microb Biochem Technol 7:1948-5948

23. Hayward AC (1960) A method for characterizing Pseudomonas solanacearum. Nature 186:405

24. Hikosaka K (2004) Leaf canopy as a dynamic system: ecophysiology and optimality in leaf turnover. Ann Bot 95:521-533

25. Jain S, Sarita K, Anukool V, Devendra KC (2016) Isolation and characterization of plant growth promoting bacteria from soybean rhizosphere and their effect on soybean plant growth promotion. Int J Adv Sci Technol Res 5:397-410

26. Janda JM, Abbott SL (2007) 16S rRNA gene sequencing for bacterial identification in the diagnostic laboratory: pluses, perils, and pitfalls. J Clin Microbiol 45(9):276

27. Karen R (2012) Carbohydrate fermentation protocol. American Society for Microbiology, New York

28. Kasim WA, Gaafar RM, Abou-Ali RM, Omar MN, Hewait HM (2016) Effect of biofilm forming plant growth promoting rhizobacteria on salinity tolerance in barley. Ann Agric Sci 61:217-227

29. Khin ML, Moe MM, Tar T, Wai ZMA (2012) Isolation of plant hormone (indole-3-acetic acid-IAA) producing rhizobacteria and study on their effects on maize seedling. Eng J 16:137-144

30. Kim PI, Ryu J, Kim YH, Chi YT (2010) Production of biosurfactant lipopeptides iturin A., fengycin, and surfactin A from Bacillus subtilis CMB32 for control of Colletotrichum gloeosporioides. J Microbiol Biotechnol 20:138-145

31. Li D, Nie F, Wei L, Wei B, Chen Z (2007) Screening of high-yielding biocontrol bacterium Bs-916 mutant by ion implantation. Appl Microbiol Biotechnol 75:1401-1408

32. Li XY, Yang JJ, Mao ZC, Ho HH, Wu YX, He YQ (2014) Enhancement of biocontrol activities and cyclic lipopeptides production by chemical mutagenesis of Bacillus subtilis XF-1, a biocontrol agent of Plasmodiophora brassicae and Fusarium solani. Indian J Microbiol 54:476-479

33. Martens H, Schweigel M (2000) Grass tetany and other hypomagnesaemias. In: Herdt T (ed) Veterinary clinics of North
America: food animal practice: metabolic disorders of ruminants, vol 16. Saunders, Philadelphia, pp 339-368

34. Methods Manual Soil Testing in India (2011) Department of Agriculture and Cooperation Ministry of Agriculture Government of India, New Delhi, January 2011

35. Moussa TA (2002) Studies on biological control of sugar beet pathogen Rhizoctonia solani Kühn. J Biol Sci 2:800-804

36. Natarajan A, Kumar MK, Usharani KG (2016) Isolation and characterization of salt tolerant plant growth promoting rhizobacteria from plants grown in tsunami affected regions of Andaman and Nicobar islands. Geomicrobiol J 33:942-947

37. Pikovskaya RI (1948) Mobilization of phosphorus in soil in connection with vital activity of some microbial species. Microbiologiya 17:362-370

38. Pospiech A, Neumann B (1995) A versatile quick-prep of genomic DNA from gram-positive bacteria. Trends Genet $11: 217-218$

39. Rabha AJ, Naglot A, Sharma GD, Gogoi HK, Veer V (2014) In vitro evaluation of antagonism of endophytic Colletotrichum gloeosporioides against potent fungal pathogens of Camellia sinensis. Int J Microbiol 54:302-309

40. Rajat RM, Ninama GL, Mistry K, Parmar R, Patel K, Vegad MM (2012) Antibiotic resistance pattern in Pseudomonas aeruginosa species isolated at a tertiary care hospital, Ahmadabad. Natl J Med Res 2:156-159

41. Riungu GM, Muthorni JW, Narla RD, Wagacha JM, Gathumbi JK (2008) Management of Fusarium head blight of wheat and deoxynivalenol accumulation using antagonistic microorganisms. Plant Pathol J 7:13-19

42. Shafi J, Tian H, Ji M (2017) Bacillus species as versatile weapons for plant pathogens: a review. Biotechnol Biotechnol Equip 31:446-459

43. Sharma A, Johri BN, Sharma AK, Glick BR (2003) Plant growth promoting bacterium Pseudomonas sp. strain GRP3 influences iron acquisition in mung bean (Vigna radiata L. Wilzeck). Soil Biol Biochem 35(887):894

44. Shternshis MV, Belyaev AA, Matchenko NS, Shpatova TV, Lelyak AA (2015) Possibility of biological control of primocane fruiting raspberry disease caused by Fusarium sambucinum. Environ Sci Pol Res 22:15656-15662

45. Siddiqui S, Siddiqui ZA, Ahmad I (2005) Evaluation of fluorescent pseudomonads and Bacillus isolates for the biocontrol of a wilt disease complex of pigeonpea. World J Microbiol Biotechnol 21:729-732

46. Singh RK, Singh DP, Solanki P, Srivastava MK, Kashyap S, Kumar SPL, Srivastava AK, Singhal PK, Arora DK (2014) Multifarious plant growth promoting characteristics of chickpea rhizosphere associated Bacilli help to suppress soil-borne pathogens. Plant Growth Regul 73:91-101

47. Singh RP, Manchanda G, Singh RN, Srivastava AK, Dubey RC (2016) Selection of alkalotolerant and symbiotically efficient chickpea nodulating rhizobia from North-West Indo Gangetic Plains. J Basic Microbiol 56:4-25

48. Singh RP, Manchanda G, Maurya IK, Maheshwari NK, Tiwari PK, Rai AR (2019) Streptomyces from rotten wheat straw endowed the high plant growth potential traits and agro-active compounds. Biocatal Agric Biotechnol 17:507-513. https://doi. org/10.1016/j.bcab.2019.01.014

49. Somasegaran $P$, Hoban HJ (1994) Handbook for rhizobia: methods in legume-Rhizobium technology. Springer, New York

50. Stein $T$ (2005) Bacillus subtilis antibiotics: structures, syntheses and specific functions. Mol Microbiol 56:845-857

51. Subhashini DV, Singh RP, Manchanda G (2017) OMICS approaches: tools to unravel microbial systems. Directorate of 
Knowledge Management in Agriculture, Indian Council of Agricultural Research: ISBN 8171641709

52. Tamura K, Daniel P, Nicholas P, Glen S, Masatoshi N, Sudhir K (2011) MEGA5: molecular evolutionary genetics analysis using maximum likelihood evolutionary distance, and maximum parsimony methods. Mol Biol Evol 10:2731-2739

53. Tan $S$, Yue $D$, Hanpeng $L$, Jianfeng $H$, Song $S$, Yangchun $X$, Qirong S (2013) Antagonistic bacterium Bacillus amyloliquefaciens induces resistance and controls the bacterial wilt of tomato. Pest Manag Sci 69:1245-1252

54. Torres MJ, Pérez Brandan C, Petroselli G, Erra-Balsells R, Audisio MC (2016) Antagonistic effects of Bacillus subtilis subsp. subtilis and B. amyloliquefaciens against Macrophomina phaseolina: SEM study of fungal changes and UV-MALDI-TOF MS analysis of their bioactive compounds. Microbiol Res 182:31-39

55. Vincent JM, Humphrey B (1970) Taxonomically significant group antigens in Rhizobium. J Gen Microbiol 63:379-382

56. Walker R, Powell AA, Seddon B (1998) Bacillus isolates from the spermosphere of peas and dwarf French beans with antifungal activity against Botrytis cinerea and Pythium species. J Appl Microbiol 84:791-801

57. Xiaojia H, Daniel PR, Lihua X, Lu Q, Yinshui L, Xiangsheng L, Peipei $H$, Changbing $Y$, Xing $L(2019)$ Seed treatment containing Bacillus subtilis BY-2 in combination with other Bacillus isolates for control of Sclerotinia sclerotiorum on oilseed rape. Biol Control 133:50-57

58. Yang S, Chen W, Wang E, Chen W, Yan J, Han X, Tian C, Sui X, Singh RP, Jiang G, Chen W (2018) Rhizobial biogeography and inoculation application to soybean in four regions across China. J Appl Microbiol 125:853-866

Publisher's Note Springer Nature remains neutral with regard to jurisdictional claims in published maps and institutional affiliations. 